tion about less common disorders with which the clinician can supplement his own personal experience. It can in this respect make available to the junior clinician a level of clinical experience which might take him years to accumulate. We ourselves plan experiments which evaluate this particular hypothesis further in respect of disorders of the large bowel.'

We are grateful to Professor J. C. Goligher for his encouragement and advice during the conduct of this study, and to Professor Goligher and Mr. D. Johnson for permission to study patients admitted under their care. We are also most grateful to Professor K. Smith and Professor M. Wells, together with the staff of the Department of Computational Science and the Electronic Computing Laboratory in Leeds for their help and advice. Two of us (D.J.L. and J.C.H.) were aided by a grant from the Medical Research Council, which we also acknowledge with gratitude. Finally, and particularly, we thank our clinicians for their efforts and their patience.

\section{References}

1 Horrocks, Jane C., McCann, A. P., Staniland, J. R., Leaper, D. J., and de Dombal, F. T., British Medical fournal, 1972, $2,5$.

2 de Dombal, F. T., Leaper, D. J., Staniland, J. R., McCann, A. P., and Horrocks, Jane C., British Medical fournal, 1972, 2, 9

Savage L J in The Foundations of Statistics. New York, Wiley, 1954

- Edwards, W. Transactions on Human Factors in Electronics, 1966, 7,

- Lusted, L. B., in Introduction to Medical Decision Making, p. 164. Springfield, Illinois, Thomas, 1968.

- Staniland, J. R., Ditchburn, Janet, and de Dombal, F. T., British Medical fournal. 1972, 3, 393 .

'Shepherd, J. A., in Surgery of the Acute Abdomen, p. 32. Edinburgh, Livingstone, 1968.

Hamilton, M., personal communication, 1970

- de Dombal, F. T., Horrocks, Jane C., Leaper, D. J., and Staniland, J. R. In preparation.

\title{
Impressions of Cogwheel
}

\section{General Practitioner}

\author{
FROM A SPECIAL CORRESPONDENT
}

British Medical fournal, 1972, 4, 354-355

To most of those general practitioners who have heard of the Cogwheel report," it is something that "they" are doing in the hospitals. The family doctor I visited, Dr. Cadwallader, was one of these. Even so, as the report points out, "liaison activities with other divisions, with other departments and committees within the hospital group, with general practitioners and with medical officers of health, to name only a few, will form an important part of the division duties."

Dr. Cadwallader runs a modern, well-staffed, group practice. His patients may be cared for in one of four hospital groups and so far there is no sign of liaison between him or his group partners and the various hospital divisions. Dr. Cadwallader charitably wonders whether the early stages of establishing the divisional and executive committee structure within the hospital groups have kept their eyes turned inwards so far. Soon he hopes that they will feel secure and wellorganized enough internally to look to their external duties to the community they serve. For he certainly has need of them. His patient, old Mrs. A. B., who is paraplegic, survives at home with three daily visits from home helps. Recently when the Seebohm report ${ }^{2}$ was implemented the new local authority social services department took over the home helo service. The home help organizer, well known to Dr. Cadwallader, used to be responsible to the county medical officer but now her boss is the director of social services. He says that the budget demands that, as the area is getting much more money than the average, some help must be withdrawn. Therefore it may not be possible to manage Mrs A. B. in her home and she will have to go into hospital.

This presents another problem. The local geriatrician sees his role as caring for illness in the aged. Mrs. A. B. is not really ill, or no more ill than she has been for years, so he may not be able to find a bed for her. In any case Seebohm reported that (in 1968) the cost of one whole time home help was "less than $£ 1,000$ per year." Even at today's prices Mrs. A. B. must cost the N.H.S. (though not the local authority) much more in hospital.

At present Dr. Cadwallader has only two or three options. He could go to the local hospital management committee, of

which he is a member. But they can only make recommendations. He could have the matter publicized, but there will be other cases and that would give diminishing returns. He could, and does, use the "old boy net." $\mathrm{He}$ is able to do this because he is a friendly, long-established, public-spirited G.P. who knows a lot of people, and has done many good turns for others. Some G.P.s have other gifts which, while making them good doctors, do not create an old boy net like Dr. Cadwallader's. What are they to do for their Mrs. A. B.s?

\section{Divisions For G.P.s?}

Dr. Cadwallader's solution to this type of problem would be to have Cogwheel divisions of general practitioners. The second Cogwheel report ${ }^{3}$ mentions that a few have been set up-some apparently for general practitioners using hospital beds, others (more what Dr. Cadwallader has in mind) to provide a more broadly based link with community health services. Dr. Cadwallader himself would not regard it as practicable to belong to a division of general practitioners in each of the hospital groups to which he sends his patients, and so he suggests that the divisions could be organized by the members of the local medical committee. In his area, this statutory body has about $\mathbf{3 0}$ members. Each member is elected by the general practitioner in his "constituency." They represent the G.P.s on the executive councils and the same organizations will be retained to represent the G.P.s on the area health boards after the N.H.S. reorganization in 1974. They used to select trainers and trainees in general practice but this function will be taken over by the regional general practitioner advisory committees. As Dr. Cadwallader sees it, the members elected for the areas covered by each of the four hospital groups could form the division of general practice. They would elect their own divisional chairman, who would then sit on the hospital group medical executive committee.

A problem like Mrs. A. B.'s, Dr. Cadwallader thinks, would then be discussed by the general practitioners, and, with any luck, the community physicians and representatives of the department of social services (who would not be doctors). An 
agreed solution between home helps and a hospital bed would probably be found. If not the matter would automatically reach the hospital group medical executive committee in the divisional minutes and could be raised by the chairman of the division there for a policy decision. In addition, with their other hats on, the members of the local medical committee will have access to the local executive committee and later to the area health boards. As within the hospital, the function intended for Cogwheel-that of communication between the deliveries of health services and the members of powerful, executive committees-would be amply served in the way Dr. Cadwallader described-and slot neatly into the 1974 arrangements.

Dr. Cadwallader thought that some individual G.P.s-for example, those with clinical assistantships-would wish to belong to specific divisions such as surgery or psychiatry, but that in his area at least such individual attachments would be no substitute for divisions of general practice and would not provide a continuing voice on the group medical executive committee. Divisions of general practice within Cogwheel would do more than anything to improve standards, he considered, to give general practitioners confidence in their own and the hospital system, and to encourage good doctors to enter general practice knowing that they would be part of a psychologically satisfying system.

\section{Other Aspects}

Dr. Cadwallader then turned his fertile imagination to other aspects of Cogwheel. $\mathrm{He}$ is also associated with a university department of community medicine (this too so far has no place in the Cogwheel structure.) In this way he is in contact with both medical students and with young trainee general practitioners (some of whom might eventually prefer to return to hospital work.) He regards it as his job to show how total medical care can be provided-by general practitioners and their staff of nurses, midwives (whether they belong to the national health service or to the district health boards), social workers, home helps, meals-on-wheels (local authorities), hospital services, and voluntary organizations. Students in particular would learn the value of all the structural links by seeing him actually use them for the benefit of patients such as Mrs. A. B. Of course, he also teaches the value of old boy nets. But for many young doctors these take years to set up and a proper structure that can neutralize the effects of negative personalities would be much more reassuring to the newcomer, and, he emphasized, to the immigrant doctor. Many of these would feel more secure with a regular system of communication than with old boy systems, with which they may not be familiar or easily admitted into-and this can also apply to doctors brought up in one part of the country when they go into practice elsewhere.

Dr. Cadwallader had not had time to read the second Cogwheel report but was not surprised to find that, of the 107 existing Cogwheel structures, only 23 had divisions in which general practitioners were represented-10 psychiatric, 12 obstetric and/or paediatric, and 1 geriatric. The few general practice divisions which had been set up had been designed as a link for general practitioners using hospital beds. The working party emphasized that these should not be used as an alternative to establishing links between other divisions and the community services, as many matters dealt with by divisions have implications for medical services provided outside the hospital.

Since the publication of the White Paper on N.H.S. reorganization ${ }^{4}$ there has been considerable criticism that Sir Keith Joseph has failed to take the opportunity to modernize the so-called back-street cottage industry with its independent general practitioners. If Dr. Cadwallader is correct, divisions of general practice would do much to raise morale and standards among general practitioners without alienating them by removing their status as independent contractors and imposing a salaried service on them.

\section{References}

First Report of the foint Working Party on the Organization of Medical Work in Hospitals. London, H.M.S.O., 1967.

The Committee on Local Authority and Allied Personal Social Services 1965-8, Report, Cmnd. 3703. London, H.M.S.O., 1968.

3 Second Report of the foint Working Party on the Organization of Medical Work in Hospitals. London, H.M.S.O., 1972. 4 National Health Service Reorganization: England. London, H.M.S.O.,

\section{Today's Drugs}

\section{Prostaglandins}

\section{British Medical fournal, 1972, 4, 355-357}

In 1935 von Euler discovered in human seminal plasma a lipid substance which stimulated smooth muscle preparations and lowered the blood pressure in rabbits. Since this active substance was thought to have been secreted by the prostate gland it was called prostaglandin. Much more recent work has shown that prostaglandins are a specialized group of hydroxy fatty acids, which exist in the natural state in all mammalian tissues so far examined, in some amphibia, and even in coral (Plexaura homomalla). Biosynthesis is from essential fatty acids. Prostaglandins are highly potent even in minute amounts and their reported pharmacological actions are both numerous and varied. Their exact role in normal homoeostasis has not yet been determined. They are not true hormones, though at least some of their effects may depend on influencing hormone actions within cells mediated by the enzyme $3^{\prime}, 5^{\prime}$ - (cyclic) AMP. In turn prostaglandins may be released from cells or tissues which have been subjected to endocrine, neural, or mechanical stimuli.

Chemically, prostaglandins are 20-carbon-atom molecules arranged in cyclopentane ring structures (see Fig.). They are

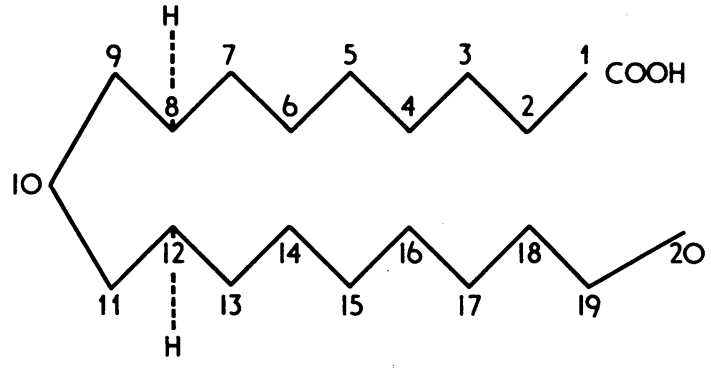

